\title{
PUBLIC GARAGES AS NUISANCES PER SE
}

\section{ROBERT RUPPIN +}

In dealing with the question to what extent and under what circumstances public garages constitute nuisances, the Supreme Court of Pennsylvania has laid down an unique doctrine, namely, that such garages in residential neighborhoods are nuisances per se, or, perhaps more accurately, nuisances as a matter of law, by reason of environment. The question is an important one and worthy of critical study, more especially because of the pronounced leaning in several other jurisdictions toward the adoption of the doctrine laid down by the Pennsylvania court. Lawyers in active practice are familiar with the constant recurrence of the question, and the extent of its importance is indicated by the fact that in Pennsylvania alone, since the decision in Prendergast $v$. Walls, ${ }^{1}$ usually looked to as the source of the doctrine, it has been before the appellate courts in one or another closely similar form no less than twenty-eight times, and before the courts of first instance of course much more often.

From a historical standpoint the doctrine is doubly unique. Noise is of course the distinguishing characteristic which marks out these establishments for special consideration; not, however, the noise of ordinary operation of motor vehicles, that is of their moving to and fro, even in large numbers, for that, like other objectionable features, such as the dangers and inconvenience due to congestion, odors, increased fire hazards, et cetera, and even when combined with them, will not of necessity constitute a nuisance. ${ }^{2}$ The noise which distinguishes the public garage is the noise due to the repairing and servicing of motor vehicles-the pounding on metals, racing of motors, et cetera, which always form the backbone of the complaint when such establishments are attacked as nuisances. This noise, as has been said, constitutes the distinguishing characteristic of the public garage, and the reason why the Pennsylvania doctrine is historically unique is that in no

† A. B., I918, Franklin and Marshall College; member of the bar of Lancaster County, of the Supreme Court of Pennsylvania, and of the Supreme Court of the United States.

${ }_{2} 25$ Pa. 547, IOI At1. 826 (I917).

"See for example Brown v. Easterday, I ro Neb. 729 at 734, I94 N. W.798 at 800 (I923), where, in holding an oil and gasoline filling station in a residential district to be neither a nuisance per se nor in fact, the court said: "Regarding the increase of traffic, the same reasoning would constitute a popular church a private nuisance, as it is a well-known fact that, not only on Sundays, but on other days and nights, when the activities of churches are in progress, automobiles are parked for blocks in all directions and to a certain extent interfere with the quiet enjoyment and privacy of homes in the vicinity, and yet these are but the trivial inconveniences necessarily resulting from changes and improvements growing out of advancing civilization. The same may be said as to the glare of the lights. . . As to the disagreeable noises, the evidence does not convince us they are of such a character as to seriously interfere with the plaintiff's comfort and enjoyment of his home." And see Pennsylvania Co. v. Sun Oil Co., $290 \mathrm{~Pa}$. 404, 138 Atl. 909 (I927), and Rhodes v. Dunbar, 57 Pa. 274 (1868). 
other instance has the law declared an establishment to be a nuisance per se whose only or chief objectionable attribute was noise. ${ }^{3}$

Our ancestors do not seem to have been so sensitive to noise. Perhaps before the Industrial Revolution there was no great occasion for them to be so. At any rate, in the old books there is practically no mention of noises as constituting nuisances, either in law or in fact. In a work as late as Blackstone noise is not mentioned as a possible nuisance. Enumerating the nuisances which affect a man's dwelling, Blackstone says that they may be reduced to three: "I. Overhanging it: . . .2. Stopping antient lights; And 3., corrupting the air with noisome smells." 4

The old books are full of cases of nuisances, most of them cases of interferences with easements, purprestures, ${ }^{5}$ pollution and diversion of water-ways, et cetera, and there are some cases of noisome odors ${ }^{6}$ (many of the old cases deal with the distinction between trespass on the case and the assize of nuisance), but cases of noises, with the exception of an interesting case in Lutwyche, to be considered presently, are conspicuous by their absence. $^{\top}$ Certainly there is nowhere any indication that an establishment may, by reason of noise, be considered a nuisance per $s e .^{8}$

3 "The test whether a nuisance exists through noise in any case depends upon all the attendant conditions. It is not open to doubt that noise alone may constitute a nuisance. . . . In order that a noise may amount to a nuisance, it must be harmful to the health or comfort of ordinary people." Rugg, C. J., in Stevens v. Rockport Granite Co., 216 Mass. 486 at 488, 104 N. E. 37 r at 373 (1914).

"Noise alone may constitute a nuisance; but in determining whether it is a nuisance, the character and volume, and the time, place, and duration ${ }_{i}$ of its occurrence, and the locality, must be considered." Peragallo v. Luner, 99 N. J. Eq. 726 at 729, I33 Atl. 543 at 545 (I926).

*3 BL. CoMra. 217 .

"For an unusual modern instance of this kind see Fugate v. Carter, I5I Va. I0S, I44 S. E. 483 (1928), where a garage was built in and over a public street, which however had not been opened but merely laid out on a plan. The garage was held to be both a public and a private nuisance.

${ }^{\circ}$ E. g. Jones v. Powell, Palmer 536, Hutton 135 ( 1651 ), where the combined odors of a brewhouse and a "quandam latrinam" proved too much for the plaintift.

T The case of Rex v. Smith, I Strange 704 (1725), in which the defendant was convicted and fined on an indictment for "making great noises in the night with a speaking trumpet to the disturbance of the neighborhood" is obviously of another type, and has been disregarded. So also has this statement from Comyns (Dig., substit. "Action upon the Case for a Nuisance.-C. When it does not Lie.") : "If a man set up a school so near my study, who am of the profession of the law, that the noise interrupts my studies," as Comyns cites no authority. By way of contrast to this statement see a recent case, where a barking dog which annoyed a physician was held a nuisance. Hechelman v. Kindt, $22 \mathrm{~Pa}$. D. R. $79 \mathrm{I}$ (IgII).

${ }^{8}$ The well-known cases in which bowling alleys were held nuisances per se were based, not on the noise incident to their operation, but on their "affording to the idle and dissolute encouragement to continue in their destructive courses," State v. Haines, $30 \mathrm{Me}$. 65 (1849), and on their tendency to be converted into "nurseries of vice and crime." Tanner v. Trustees of the Village of Albion, 5 Hill I21 (N. Y. 1843). It is hardly necessary to add that the modern cases have changed the rule and that bowling alleys are no longer nuisances per se. Peragallo v. Luner, supra note 3; Hamilton Corp. v. Julian, 130 Md. 597, ror. Atl. $55^{8}$ (I917).

For a modern case, where a bowling alley located in a business section was held to be a nuisance on the facts by reason of noise, see Briggs v. Vottler, 4 Wkly. Not. Cas. 272 (Pa. 1877). 
The case in Lutwyche is Bradley $v$. Gill, ${ }^{9}$ decided at the Hilary Term, $3 \& 4$ Jac. 2. It was an action for a nuisance, wherein it was alleged that the defendant conducted "quandam Shopam Fabrilem (Anglice a Smith's Shop)." and that he, "tompore nocturno ac" tempore matitino ante lucem diei \& ad.al' tempora \& horas intempestivas 10 . . . cum malleis ferreis percussit, ita quod per horribiles stridores, clangores, strépitus \& sonitus laboris \& din'erberationis . . . domire, quiescere sen manere non potuir' nec possunt." The defendant pleaded that for more than twenty years he had been occupied as a smith in Stowrbridge, and that the plaintiff had invited him to use his trade there. The court sustained a demurrer to the plea, holding that the action lay, that the plea did not respond to the declaration, and that the "traverse fuit idle." But by consent the defendant had leave to amend. The case was of course dealt with as one involving a nuisance in fact rather than a nuisance per se. It will be noted that the declaration, with its "horribiles stridores, clangores, strepitus \& sonitus" humorously foreshadows the complaints in the garage cases of today. The allegation of hammering "cum malleis ferreis" is the literal forerunner of the now stereotyped allegation of pounding and striking on metal met with in practically every garage case.

For about a hundred and fifty years there do not seem to have been any similar cases reported in England. Then, near the middle of the nineteenth century, we find a number of cases, some of them, as might be anticipated, resulting from the use of steam, and we find the interposition of equity to enjoin noises and other nuisances becoming frequent. ${ }^{11}$ As for example, in Ball $v$. Ray, ${ }^{12}$ where the keeping of horses next to a dwelling was enjoined because of the noise issuing from the stable.

At about the same time we have the first reported case in Pennsylvania in which noise was held to be a nuisance-Demis v. Eckhardt, ${ }^{13}$ where a tin-smith's and sheet-iron worker's shop was held to be a nuisance in fact. Cases of noises as nuisances had by this time become frequent, and of course there never could be any doubt as to the general principle that excessive noise might constitute a nuisance in fact, the test being whether the

${ }^{9}$ I Lutwyche 69 (I688).

${ }^{10} \mathrm{An}$ amusing literary parallel of a much earlier date may be recalled in Chaucer, in the Miller's Tale, where Gervais the smith was sharpening; "schar and cultre bysily" at a time when, we are told, "Derk was the night as picche or as a cole."

II For the origin and antiquity of the jurisdiction of equity to restrain nuisances, see Earl of Ripon v. Hobart, 3 Myl. \& $\mathrm{K}$. I69 (I834); I AMES, CASES IN EQUITY JuRISDICTION (I904), Ch. 4, § 4, p. 553 ff., and 2 Holdsworth, History OF ENGLISH LAW (3d ed., I923), 249 et passim.

${ }^{12}$ L. R. 8 Ch. App. 467 (I873). And see Broder v. Saillard, L. R. 2 Ch. Div. 692 (I876), where a similar situation existed. Also Elliotson v. Feetham, 2 Bing. N. C. I34 (1835); Dawson v. Moore, 7 C. \& P. 25 (1835); Eaden v. Firth, I Hemming \& Miller 573 (I863); Gaunt v. Finney, L. R. 8 Ch. App. 8 (I872), and Mumford v. Oxford, etc., Ry. Co., I H. \& N. 34 (1856).

${ }^{43} 3$ Grant 390 (Pa. I862). 
noise was such "as to interfere with the ordinary use and enjoyment" of the dwelling house "so as to cause serious annoyance and disturbance." 14

With the introduction of the automobile and the establishment of public garages, the Pennsylvania court began the development of the anomalous doctrine which has been referred to, and which, as stated in its own language, is that a public garage is not a nuisance per se but becomes one when established in a residential district.

To say that a thing which is not a nuisance per se may become one under certain circumstances is, obviously, a contradiction in terms. A nuisance per se is "a nuisance in itself, and which therefore cannot be so conducted or maintained as to be lawfully carried on or permitted to exist," ${ }^{15}$ that is, it is something which is a nuisance at all times and places and under all circumstances. In spite of the instinctive tendency to call up the image of the saxophone player, it is difficult to conceive of such nuisances. It is even possible to believe that amidst the bagpiping of the Scotch Highlanders the saxophone might not be an unwelcome diversion. ${ }^{10}$ The fact is that the term "nuisance per se" is and always has been unsatisfactory. Strictly construed it is doubtful whether any such thing exists, and the declaration of the Pennsylvania court, while literally incorrect, is not so entirely illogical as on first blush it seems to be. As well said by Kephart, J., in Nesbit $v$. Riesenman," "We know that a horse-boiling factory is a nuisance per se if a use of property is attempted for that purpose within inhabited territory, yet situated distant from any habitation it certainly would not be a nuisance." 18

The origin and development of the Pennsylvania rule are interesting. Prendergast $v . W_{\text {alls }}{ }^{19}$ is usually cited as the case in which it originated. It certainly is the first reported case in the Pennsylvania appellate courts on the subject. ${ }^{20}$ But when we examine the report we find, as in so many other instances, that it is very far from laying down the rule for which it is cited. The establishment sought to be enjoined, and ultimately enjoined,

${ }^{14}$ Sir George Jessel, M. R., in Broder v. Saillard, supra note 12.

15 Cooper v. Whissen, 95 Ark. 545 , 130 S. W. jo3 (I910).

${ }^{10}$ See Miller v. Jersey Coast Resorts Corp., 98 N. J. Eq. 289 at 299, r30 Atl. 824 at 828 (I925), where it was said: "It is quite true that a class of music which may be entertaining to one may be annoying to another, but those who enjoy the modern jazz cannot be restrained from producing it because it offends the classical ear."

${ }_{17} 298 \mathrm{~Pa} .475$ at 485,148 Atl. 695 at 698 (1930).

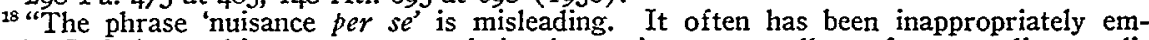
ployed. Strictly speaking, no act or omission is a nuisance regardless of surrounding conditions. No one can create a nuisance in the absence of some one affected by the former's act or omission. A slaughterhouse that would annoy no one if situated in an uninhabited gulch might be an intolerable menace to health when located in the residence sections of a city or town. The circumstances may be such as to render the most exquisite music both annoying and injurious." Colton v. South Dakota Central Land Co., 25 S. D. 309 at 313, 126 N. W. 507 at 508 (I910).

19 Supra note I.

${ }^{20}$ Hibberd v. Edwards, 235 Pa. 454, 84 Atl. 437 (1912), was a garage case, but no question of nuisance was involved. The erection and maintenance of the garage were held to violate a building restriction. 
was a one-story public garage at the corner of 38 th and Chestriut Streets in Philadelphia. The chancellor found as facts that the immediate neighborhood was exclusively residential in character, and that by the erection of the garage the peaceful enjoyment of the homes would be permanently interfered with, the lives and safety of children endangered, worship in nearby churches interfered with, values of surrounding properties reduced and insurance rates increased. These findings were based on the primary findings that if the garage were erected and operated according to specifications, there would be noises, resulting from pounding on metals, testing of engines, speeding and racing of motors, and continuous sounding of horns, odors from gasoline and smoke from motors, that the exit and entrance of cars would be dangerous to pedestrians and especially to children, that there would be congregating of persons in and about the property, and danger of conflagration. The chancellor held that under the facts found the proposed garage would be a nuisance. In a brief Per Curiam opinion the Supreme Court affirmed the decree, specifically on the chancellor's findings of facts.

In Hohl $v:$ Modell 21 there was a restriction "that there shall not be erected upon said Iot . . . any establishment for . ... any offensive business." The chancellor restrained the enlargement of a public storage garage holding ten cars so that it would house twenty-four cars, on the ground that such an establishment came within the restriction, finding that the section was exclusively residential and making the usual findings that there would be pounding on metals, etc. On appeal, the court affirmed the chancellor's findings and conciusions, and, citing Prendergast v. Walls, added: "Equity may ${ }^{22}$ restrain às a nuisance the operation of a public service garage in an exclusively residence section, aside from any building" restriction."

In Phillips $v$. Donaldson ${ }^{23}$ there was a restriction against the carrying on of any "noxious or offensive trade, business or employment, to the hurt, damage or annoyance of others who have purchased or may hereafter purchase in said plan." A bill was filed against the operation of a public garage. The court below dismissed the bill, holding that it was necessary to show a public nuisance to bring the use within the restriction. The Supreme Court reversed, holding there was evidence from which the chancellor should have found that the proposed use would be "offensive" in violation of the restriction. It refused to decide whether a garage in a residential district constituted a nuisance as a matter of law, without regard to its effect upon the neighboring properties, and said: "It is argued we should take judicial notice of the fact that in the operation of a public garage

\footnotetext{
${ }_{264}$ Pa. 5I6, ro7 Atl. 885 (I9I9).

Italics the writer's.

$=269 \mathrm{~Pa} .244$ at 247 , II2 Atl. 236 at 238 (I920).
} 
there exist such accompanying disturbances or ather conditions as will make it obnoxious and a violation of the covenant, urging that, without proof of probable annoying conduct, it would be a muisance in a residential district. ${ }^{-4}$ Because of their extensive use and the general knowledge of such use, we might be inclined to agree, but it is not necessary to so decide in the present case," ${ }_{25}$ holding that under the evidence an offensive use had been shown.

In Hunter $v$. Wood ${ }^{26}$ there was a restriction that the premises should not be used as a "commercial establishment or for any offensive purpose or occupation." The building to be erected was to be used partly as an automobile showroom, and partly as a public garage and service station. This was held to come within the restriction. The court added what was unnecessary to the decision, that "this Court has heretofore held that a public garage in a residential section is a nuisance regardless of the violation of a restriction in a deed forbidding the use of the premises for offensive purposes or occupation," citing Prendergast v. Walls, Hohl v. Modell and Phillips a'. Donaldson.

In Slingluff $v$. Tyson ${ }^{27}$ it was proposed to erect a showroom, and a service station to be used merely for the purpose of rendering service to each purchaser of a Paige or Jewett automobile. No machinery of any kind was to be installed, and only minor repairs were to be made on the premises, it being intended to send the cars to other establishments for major repairs. No gasoline or oil was to be stored for sale. The court made the usual finding of facts, much as in Prendergast $v$. Walls, as to the proposed business. On appeal the Supreme Court said, "While a business of this character might be unobjectionable where comparatively few cars of the type mentioned are sold and used, yet it is a matter of general knowledge that Paige cars are used extensively and, judging by the size of defendant's proposed building, the number of cars brought in for service and minor repairs would be so large as to practically eliminate all difference between defendant's business and that of the average public garage." And further, "The operation of a public garage in a neighborhood of this character should be restrained as a public nuisance."

Tyson v. Coder ${ }^{28}$ was decided by the Superior Court. The proposed erection was a public garage and the chancellor made the usual findings in the event that "the proposed garagn is erected and operated according to the plans." 20 The court said, "It may be considered as a settled principle of equity therefore that the business of maintaining a public service garage in a municipal neighborhood exclusively residential will be restrained where

\footnotetext{
e* Italics the writer's.

25 Italics the writer's.

$277 \mathrm{~Pa}$. 150, 120 At1. 781 (1923).

${ }^{27} 280 \mathrm{~Pa} .206$ at 208,124 Atl. 420 at $42 \mathrm{I}$ (1924).

${ }^{2} 83$ Pa. Super. II6 at I24 (1924).

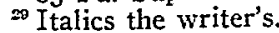


such busincss is showen to be destructive of or prejudicial to the quiet and ordcrly condition of the neighborhood and the confort and enjoyment of occupants of the residences in the vicinity ${ }^{30}$ because of noises, offensive odors, and the obstruction of the streets and footways incident to the business proposed to be carried on."

In Mitchell $v$. Guaranty Corporation ${ }^{31}$ we first see the present doctrine stated in an unequivocal form." The court said, "A public garage, from which a public service station differs only in name (Slingluff, et al., v. Tyson, $280 \mathrm{~Pa} .206$ ), is not a misance per se, but becomes such in fact when conducted in a residential neighborhood," 32 for which it cited Prendergast $v$. Walls, Slingluff v. Tyson, Hunter v. Wood, Phillips v. Donaldson, Hohl v. Modell, Hibberd $v$. Edwards and Tyson v. Coder, going on to say, after a discussion of the findings, "The annoyances incident to the business of a public garage, or public service station, regardless of the manner of its construction or operation, ${ }^{33}$ are such as to require its exchusion from residential neighborhoods." 34

That this decision was understood by the lower courts as laying down an unvarying rule is evidenced by the case of Fleagle $v$. Stokes, ${ }^{35}$ where it was said, "It is now well established in Pennsylvania that a public garage, though not a nuisance per se, becomes such in fact when conducted in a residential neighborhood . . He [the defendant] has planned to take every precaution possible against fire, and to reduce the annoyance of the business by every possible means. But in view of the positive rulings of the appellate courts, there is but one question for determination, and this is a question of fact-Is the immediate neighborhood where the intended garage is to be built predominantly residential in character?"

The rule thus laid down was confined to public garages. As to private garages the general rule was still applied, in LaRossa v. Forte ${ }^{36}$ and George v. Goodovich. ${ }^{37}$ In the latter case a series of individual private garages on both sides of a narrow alley was held a nuisance in a residential district, on findings of noise, odors, etc., and in which the court said: "The question as to what constitutes a nuisance depends upon the nature and result of the acts of which complaint is made and not upon the means by which produced or the particular description applied to them." . In Pennsylarania Company v. Sun Oil Company ${ }^{3 s}$ a demurrer to a bill to enjoin the erection of gasoline tanks was sustained because of the absence of an averment that the tanks

\footnotetext{
so Italics the writer's.

${ }_{21} 28$ Pa. 36I, I29 Atl. II4 (I925).

is Italics the writer's.

33 Italics the writer's.

3. But see what was said of this case in Burke v. Hollinger, infra note 42.

${ }^{3} 40$ York Co. I93 at 194 ( $\mathrm{Pa}$. 1927).

${ }^{33} 92 \mathrm{~Pa}$. Super. 450 (1927).

$3: 288$ Pa. 48, I35 Atl. 7 I9 (I927).

${ }^{23}$ Supra note 2.
} 
were improperly constructed or equipped. In- distinguishing such tanks from nuisances per se, the court cited as an example of the latter, "a public garage, which is inseparable from the noise of pounding metals, noxious odors, racing motors, and other affecting causes." Phillips $v$. Donaldson, Hibbcrd v. Edwards and Prendergast v. Walls were cited.

In Camey v. Pesn Oil Company ${ }^{39}$ public service gasoline and filling stations were brought under the ban, and the operation of such a station, which had been erected before the bringing of the suit, was enjoined, although there was testimony of noises, vibrations, blowing horns, changing tires, racing engines, etc., and corresponding findings of fact which rendered the application of the doctrine of Mitchell $v$. Guaranty Corporation unnecessary.

In Ladner v. Siegel, (No. I) ${ }^{40}$ the new rule was reiterated. No repair work was to be done in the proposed garage, which was to be used for storage and for the supply of gasoline to motors stored there. The building was attractive, congestion was minimized by a large entrance, the construction was designed to decrease noise, and a ventilating system was installed to remove odors, as to which however the court said, "It may be observed, the transfer of the same to the outside air will not protect the neighborhood from the injury arising from the pollution of the atmosphere." In enjoining the operation of the garage the court said: "A given business will . . . constitute a nuisance per se when it is generally known to be injurious to health and to cause legal damage to property in certain localities and surroundings, regardless of how it may be carried on, for the common experience of mankind, of which the courts take judicial notice, proves this to be the result, and such pursuits in certain areas are to be prohibited. Penna. Co. v. Sun Co., 290 Pa. 404, 4To. . . . Though a public garage is not a misance in itself, yei it becomes such when conducted in a residential neighborhood. . . . Having determined the character of the community. and use of the building intended, it was unnecessary to specifically find it constituted a misance in fact, for this conclusion followed as a matter of law." 41 Refusing appellants' suggestion that permission be granted to operate under the court's supervision, to demonstrate that no injury in fact would result, the court said: "We have held that the present intended use is a nuisance per se when carried on in a residential community, and to permit experiments in separate instances, to determine the extent of the harm suffered, would lead to endless disputes."

In the next case, Burke v. Hollinger, ${ }^{42}$ the court was brought face to face with the intolerable consequences of an inflexible application of the

\footnotetext{
${ }^{39} 291 \mathrm{~Pa} .37 \mathrm{I}$, I40 Atl. 133 (1928).

${ }_{20} 293 \mathrm{~Pa} .306$ at 309 , I42 Atl. 272 at 273 (I928).

41 Italics the writer's.

$2296 \mathrm{~Pa}$. 5IO, I46 Atl. II5 (I929).
} 
doctrine which it had laid down, by a situation which required, as it rather cryptically remarked, "not a modification of our rules as announced in the previous cases, but a limitation of their effect in given localities under certain conditions," adding that "The rule that a public garage is a nuisance per se in a residential district was first announced many years ago. ${ }^{43}$ It must be observed, without receding from this rule, that some of the reasons which prompted it have in different localities disappeared while others remain." The application of the doctrine, if applied as it was invoked in that case, would have barred public garages from extensive sections of the city of Philadelphia and of other large cities, solely on the ground that those sections were predominantly residential in character. The inconvenience thus brought about, as the court was quick to realize, would have far outweighed the disadvantages resulting from the erection of garages, which might not necessarily from their mode of operation cause serious annoyance or physical damage. ${ }^{4 \neq \cdots}$ The facts were that a garage on Latimer Street, a small side street in Philadelphia, commercial in character, was sought to be enlarged so as to run through to Spruce Street, a residential street between Fifteenth and Sixteenth streets. The entrance to the garage was to remain on Latimer Street, no entrance was to be constructed on Spruce Street, and there was to be nothing in the design of the Spruce Street side of the building to indicate that it was to be used as a garage. In the rear section, facing Spruce Street, no cars were to be washed or repaired. A solid wall was to be constructed on both sides, and gases were to be removed so as not to cause noticeable impurities in the air. The éntire structure was to house three hundred and fifty cars. The court based its refusal to enjoin the construction on the ground that the district in question, although residential in character, bordered on a large and expanding commercial district, and that therefore the convenience of the construction to the public outweighed the annoyance which might result from it. ${ }^{4 \overline{5}}$ Certainly, so far as inhabitants of the residential district are concerned, there is no logic in saying that the proximity of a commercial district would result in any excess of convenience which would overbalance the consequent annoyance of public garages. In fact the logic is all the other way. The proximity of a commercial district in which garages could be operated without restriction would $r$ ender less necessary, and consequently less convenient, the

${ }^{43}$ Four, to be exact. Mitchell v. Guaranty Corp., supra note 31.

"See Ladner v. Siegel (No. 2), $296 \mathrm{~Pa} .579$ at 589, I46 Atl. 710 at 712 (1929), where it was said: "A policy which continues to shut out all accommodation for automobiles in residential sections such as this one must necessarily inconvenience the traffic. It must seriously challenge judicial attention, as such districts are thickly inhabited centers."

"See this idea expressed in Rankett's Case, 3 Ja. B. R. (Fol. 139): "If a man makes candles in a vill, by which he, causes a noisome scent to the inhabitants, yet this is not a nusance; for the needfulness of them will dispense with the noisomeness of the smell." Cited in 16 VINER's ABR. 23; subtit. Nuisance $(F)$. But see the note therein. See also Bloch v. McCown, infra note 59, and Nevins v. MIcGavack, infra note 60. 
presence of public garages within the residential district itself. As to the occupants of the commercial district, garages for their convenience may be erected in the commercial district itself, without restriction, and there is no necessity for lifing the ban in residential districts on their behalf. The reason given by the court, that "the acquisition of expensive land in strictly commercial centers is often out of the question," is not very cogent. The court however proceeded to modify its previously announced rule by setting up a classification into three distinct types of districts, its decision therefore becoming nothing more nor less than a zoning regulation. It said: "The manner of construction and operation of a public garage becomes important in determining, in certain districts, ${ }^{46}$ whether its use should be prohibited. Other important considerations make it necessary for an advance to be made in the law governing the use of buildings for public garages. . . . When considering the location of a public garage, the reasons for prohibiting it must be limited in the third type when that district reaches or bears on a conmercial center in a rapidly growing city." And this from a court which had set aside the report of a master which held that a steam planing mill "could hardly, in the common course of things, be used without working mischief to the properties of the plaintiffs and other property in the neighborhood-by causing annoyance, inconvenience and discomfort; by exposing such property to the risk of destruction or damage by fire; and by depreciating its value and hindering improvements of a class suited to, and such as would naturally seek that locality," and said that it presented for consideration "a subject not within our sphere of judicial action. It presents a question of policy whether a part or portion of a city ought to be devoted exclusively to private residences or other special objects; and that is manifestly for the local authorities or the legislature to determine, and not us. That concerns alone the public, and not private parties. With peoples' rights we deal in cases like the present, and not with questions of mere policy, local or general." "4T The court disposed of Mitchell $v$. Guaranty Corporation by saying, "The ruling consideration in that case may safely rest on the principle that the decision of the chancellor, not being an abuse of discretion, is final. There were circumstances there mentioned which justified the order, the degree of proximity of near-by businesses and the danger to school children being prominent."

In Ladner $v$. Siegel (No. 2) ${ }^{4 s}$ the rule as modified in Burke v. Hollinger was applied. This was a proceeding for contempt arising out of an alleged violation of the injunction in the previous case. The defendants had attempted the establishment of the garage according to modified plans. The Superior Court held that in so doing the defendants had not violated

"Italics the writer's.

"Rhodes v. Dunbar, supra note 2.

${ }^{48}$ Supra note 44 . 
the injunction. The Supreme Court reversed the Superior Court, but in view of the modification which, in the interim, had been made in Burke v. Hollinger and which was applicable, modified its original judgment, subject to the defendants purging thenselves of the contempt. The Supreme Court said: "The use of a building for the storage, service or repair of a number of automobiles is not a nuisance per se in a section devoted to business purposes (Phillips v. Donaldson, 2ó 9 Pa. 24t), as this statement is further explained in the Hollinger Case, but such use for any of these purposes does become a nuisance per $s e$ in a residential section. In considering the place where the use was to be made, the primary question was and still is whether the section is exclusively residential; as to such the use was and still is a nuisance per se... . In third class residential districts a garage properly built to, under or around an apartment house is not a nuisance por se. Its use, however, from the fact of operation may become a nuisance. In such districts the method of construction and operation should conform to that laid down in the Hollinger case."

In Nesbit $v$. Riesenman ${ }^{49}$ the original rule was applied in its full rigor to a case arising in: a small city; and the constitutional right of the court to make and enforce a classification of this kind was upheld..$^{50}$ In Long $v$. Firestone ${ }^{51}$ the same rule was again affirmed in enjoining the operation of a filling and service station in a residential district of the City of Reading. In Sprout $v$. Levinson ${ }^{52}$ the converse of the rule-that in a non-residential district an actual nuisance must be shown-was reaffirmed.

The sum total of the decisions in Pennsylvania to date seems to be that outside of large cities and what that term includes has yet to be decided-a public garage, filling or service station is a nuisance as a matter of law, in a residential district, regardless of the manner of its construction or operation. In large cities the classification laid down in Burke v. Hollinger is to be applied, and if the section in question; although residential, borders on a commercial district, to warrant the injunction or abatement of the establishment there must: be proof that its operation would constitute a nuisance in fact.

The dangers of this dactrine, which so far as logic is concerned, paves the way for courts to restrict the legitimate operation of businesses in certain sections, even in the face of proof that the operation will not result in what has been hitherto recognized as a nuisance, is apparent without the necessity of much supporting reasoning, ${ }^{53}$ and it is hardly necessary to add

'Supra note I7.

${ }^{2}$ Certiorari denied; 28I U. S. 754, 50 Sup. Ct. $40 S$ (1930).

c1 $303 \mathrm{~Pa}$. 208, I54 Atl. 364 (193I).

$\approx 29 \mathrm{~S}$ Pa. 400, I4S At1. 5 II (1930).

ss See for example, Saier v. Joy, Ig8 Mich. 295, I6 4 N. W. 507 (I917), a case antedating the Pennsylvania garage cases, where an undertaking establishment was excluded from a residential section without proof of actual injury. 
that the doctrine thus laid down by the Pennsylvania court is opposed to the weight of authority.

In some jurisdictions the suggestion that a public garage is a nuisance per se in a residential district has been expressly repudiated. In Brown $v$. Easterday, ${ }^{54}$ for example, the Supreme Court of Nebraska said, in a case involving an oil and gasoline filling station located in a residential district: "The contention is made that the location in question is in a purely residence district, which should not be invaded for the purpose contemplated. A sufficient answer would seem to be that, in the absence of legislation dividing the city into zones and having a general application to all property within the respective sections, it is not within the power of the courts to interfere with the lawful use of property by the owner." And in Sherman v. Levingston, ${ }^{55}$ Merrell, J., said: "I an convinced that a pullic garage may be so conducted that its objectionable features may be eliminated, or at least minimized to an extent that its operation will not unduly annoy or inconvenience those who reside nearby." 56 In Texas and Michigan the trend, as evidenced by the expressions of the courts, is in the direction of the Pennsylvania rule. There has been however no direct adoption of the rule, the expressions in favor of it being first in a case in which on the facts a garage was held to be a nuisance, ${ }^{57}$ and second in a case in which the district was held not to be a residential one. ${ }^{j s}$ The nearest approach to the adoption of the Pennsylvania doctrine is in Bloch v. $M c C o w n,{ }^{59}$ where the Alabama court held, on a demurrer to a bill filed to enjoin the operation of a gasoline filling station and tire repair shop, which averred merely the "inevitable incidents" of operation of such an establishment, that the demurrer should be overruled, saying: "The facts remain to be proved, though the bill may be aided to some extent by common knowledge." The prior decision in Nevins v. McGavack, ${ }^{60}$ where the court had held the question to be one of fact, was distinguished, on the ground that there was a general public necessity for the existence of garages, but none for the existence of gasoline filling stations and tire repair shops. The Pennsylvania case of Tyson v. Coder was cited and followed with approval.

The Pennsylvania doctrine stands upon a false premise, namely, that injury to the neighborhood is an inevitable and necessary consequence of

st Stupra note 2.

${ }^{5}$ I28 N. Y. Supp. 58r at 583 (Igro).

${ }^{\circ}$ Pauly v. Montgomery, 209 Iowa 699, 228 N. W. 648 ( I930) ; State v. Wade, I28 Kan. 646, 278 Pac. 1067 (1929) ; True v. McAlpine, 8I N. H. 3I4, I25 Atl. 680 (I924); Bourgeois v. Miller, 89 N. J. Eq. 285 , rof Atl. 383 (19r8), accord. And sce Ballstadt v. Pagel, 202 Wis. 484,232 N. W. 862 (1930).

I.emis v. Berney, $230 \mathrm{~S}$. W. 216 (Tex. Civ. App. ro2i).

s Moore v. Johnson, 245 Mich. I73, 222 N. W. I20 (I928). "A careful perusal of the cases decided in other jurisdictions leads to the conclusion that each case must stand or fall largely upon its own facts." Ballstadt v. Pagel, supra note 56 at 489,232 N. W. at 864 .

${ }_{50} 219$ Ala. 656, I23 S. 213 (I929).

${ }^{2} 24$ Ala. 93, I06 S. 597 (I925). See the dissent of Gardner, J., who said, citing the Pennsylvania cases: "Its objectionable features are inherent in the business." 
the operation of a public garage. That this is no longer a fact is evidenced by the cases themselves which have endeavored to adhere to the rule in the face of demonstration that such consequences may be dispensed with. Nor is it any longer necessary from an aesthetic standpoint that these establishments be barred from residential districts, even if such considerations were sufficient to sustain the doctrine, ${ }^{61}$ as shown by the leading cases of Burke v. Hollinger and Ladner $\%$ Siegel, where it was part of the case proposed to be established that the garages would conform to the general aesthetic and artistic requirements and standards of architecture of the neighborhood. The doctrine therefore resolves itself into a purely arbitrary one, to wit, that by judicial fiat public garages may not be established in residential neighborhoods.

Regardless of the consideration that to invoke judicial interference some resident of the neighborhood must have at least a fancied grievance and some private interest, and that therefore the doctrine laid down by the courts does not operate automatically to exclude garages from residential neighborhoods, which, it may be remarked, is also to a certain extent true of legislation, it is the principle laid down that is dangerous, that is, that courts may depart from the rules of the common law, and, conceding that certain things are neither nuisances per se by the old law, nor, in the orthodox sense, by the present law, hold them to be nuisances per se in certain restricted localities, and then superimpose arbitrary rules for determining the nature and character of those localities. ${ }^{62}$

The progress of modern science does not justify anything being called a nuisance per se which is not contra bonos mores, because, as has been demonstrated in these garage cases, that which may seem to be the inevitable consequence of a trade or industry in one decade may have been entirely eliminated by the arrival of the next decade. It is particularly vital that establishments which are useful and of some benefit to a community shall not be excluded therefrom by reason of pre-conceived notions as to their inevitable consequences, but that each case shall be left to its own facts, and that the old and well grounded rule shall be maintained that a nuisance must be proven by showing that its maintenance will either cause actual physical damage to property or a substantial interference with health and

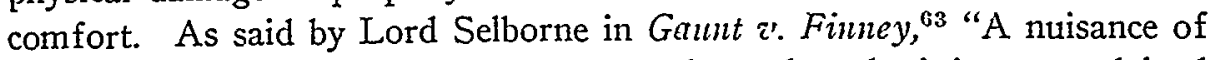
this kind is much more difficult to prove than when the injury complained

as to this, see Neff v. Gorman, 303 Pa. I86, I54 Atl. 293 (I93I), holding that an "eyesore" may be a nuisance, and Walnut \& Quince St. Corp. v. Mills, 303 Pa, 25, I54 Atl. 29 (1931).

The rules to be applied in making this determination are set forth in Mitchell v. Guaranty Corp., supra note $3 \mathrm{I}$; Nesbit v. Riesenman, supra note 17 , and Burke v. Hollinger, supra note 42, and in Krocker v. Westmoreland Co., $274 \mathrm{~Pa}$. I43, II7 At1. 669 (I922); Hamilton v. Bates, $284 \mathrm{~Pa}$. 513, I3I Atl. 369 (1925); and Unger v. Edgewood Garage, 287 Pa. I4, I34 Atl. 394 (1926).

¿'supra note 12. 
of is the demonstrable effect of a visible and tangible cause," but the diffculty of proof should not dispense with the necessity of showing something beyond a mere fanciful or imaginary injury, and we may agree with the statement in the same case that, "a nuisance by noise (supposing malice to be out of the question) is emphatically a question of degree."

The Pennsylvania cases lay down a doctrine which is not only illadvised, but which was originally based upon a line of cases giving it no support, and the later cases, which laid it down unequivocally and gave it general application, being already weakened by the modification introduced in Burke v. Hollinger, should, when the proper occasion arises, be overruled. ${ }^{64}$

as Since this article is written the cases of Yeager v. Traylor, I60 Atl. I08 ( $\mathrm{Pa}$. I932), and Pilling v. Moore, 160 Atl. I09 ( $\mathrm{Pa}$. 1932), have been decided by the Pennsylvania Supreme Court. They have further modified the rules, by giving to owners of apartment houses the right to attach garages for the use of their tenants, even in residential sections of smaller cities. 